\title{
ACID-BASE CHANGES FOLLOWING EXCHANGE TRANSFUSION WITH CITRATED BLOOD
}

\author{
BY \\ MARY CALLADINE, DOUGLAS GAIRDNER, B. T. NAIDOO, and D. H. ORRELL \\ From the Cambridge Maternity Hospital and the John Bonnett Laboratories, United Cambridge Hospitals
}

(RECEIVED FOR PUBLICATION MARCH 26, 1965)

The acid-citrate-dextrose (ACD) solution used to preserve blood consists in effect of 2 parts trisodium citrate to 1 part citric acid. It forms a buffer solution such that the $p \mathrm{H}$ of bank blood less than 5 days old is, in our experience, $6 \cdot 6 \pm 0 \cdot 2$. It can be predicted, therefore, that infusion of ACD blood must lead to an initial acidosis, and that this will in due course be replaced by a metabolic alkalosis as citrate is metabolized to form 3 moles of sodium bicarbonate for each mole of trisodium citrate retained. In the individual subject, the rates at which these two effects operate will determine the severity of the initial acidosis, and the stage at which the later alkalosis develops.

\section{Material and Methods}

The babies studied received exchange transfusion for $\mathrm{Rh}$ or $\mathrm{ABO}$ haemolytic disease, or, in one case, for unexplained hyperbilirubinaemia. Their ages varied between 3 hours and 7 days. Two blood volumes (i.e. $180 \mathrm{ml} . / \mathrm{kg}$.) were exchanged in the course of 2 hours. In about half the cases both umbilical artery and vein were utilized for the transfusion, the baby's blood being allowed to drip from a catheter placed in an umbilical artery, while being replaced by donor blood dripped into a catheter placed in the umbilical vein. In the remaining cases the conventional intermittent method was used, with $20 \mathrm{ml}$. aliquots taken and given via the umbilical vein. Calcium gluconate $0 \cdot 1 \mathrm{~g}$. was given with every $100 \mathrm{ml}$. transfused.

Donor blood was less than 5 days old. The ACD routinely used in this area has the composition shown in Table 1. This provides rather more citrate than the formula commonly used which has $\mathbf{2} \mathbf{g}$. disodium citrate.

The donor blood was usually concentrated by the removal of about $150 \mathrm{ml}$. supernatant plasma. The final analysis varied somewhat on account of the variable haematocrit of the donor's blood, but from analyses of 24 bottles ( 8 analyses for citrate) the average composition of bank blood after concentration was as given in Table 2 (values for a normal baby are quoted for comparison).
Blood samples were obtained during the course of transfusion either from the aorta via umbilical artery catheter, or from the umbilical vein when the artery had not been catheterized. In practice there was little difference between the analyses of samples from the two sources, as blood from the region of the portal vein is almost arterial in character. Furthermore, plasma bicarbonate, with which we were chiefly concerned, is substantially the same in venous and arterial blood (Gandy, Grann, Cunningham, Adamsons, and James, 1964). After the end of transfusion, samples of 'arterialized' blood were obtained by skin-prick of the wellwarmed foot. Samples were analysed without delay by the Astrup technique for $p \mathrm{H}, \mathrm{PCO}_{2}$, and bicarbonate; the latter has been expressed throughout this paper in terms of standard bicarbonate (Astrup, Jørgensen, Siggaard Andersen, and Engel, 1960), as this provides a convenient measure of metabolic acidosis and alkalosis. Chloride was measured by electrometric titration. Citrate was measured by the method of McArdle (1955).

TABLE 1

COMPOSITION OF ACID-CITRATE-DEXTROSE

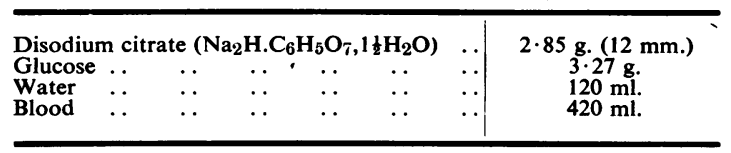

TABLE 2

AVERAGE COMPOSITION OF BANK BLOOD AFTER CONCENTRATION

\begin{tabular}{|c|c|c|c|c|}
\hline & & & $\begin{array}{l}\text { Donor } \\
\text { Blood }\end{array}$ & $\begin{array}{c}\text { Blood of } \\
\text { Normal Baby } \\
\text { (1st week) }\end{array}$ \\
\hline 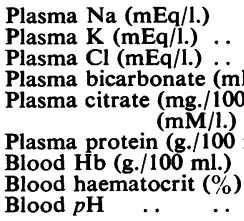 & $\begin{array}{l}\cdots \\
\cdots \\
\text { /i.) } \\
\text { l.) } \\
\ldots \\
\ldots \\
\ldots\end{array}$ & $\begin{array}{l}\cdots \\
\cdots \\
\cdots \\
\cdots \\
\cdots \\
\cdots \\
\cdots \\
\cdots\end{array}$ & $\begin{array}{l}160 \\
6 \cdot 8 \\
63 \\
6 \\
620 \\
32 \cdot 3 \\
6 \cdot 7 \\
13 \\
42 \\
6 \cdot 6\end{array}$ & $\begin{array}{c}134 \\
4 \cdot 0 \\
104 \\
23 \\
<4 \\
<0 \cdot 2 \\
6 \cdot 2 \\
19 \\
57 \\
7 \cdot 4\end{array}$ \\
\hline
\end{tabular}




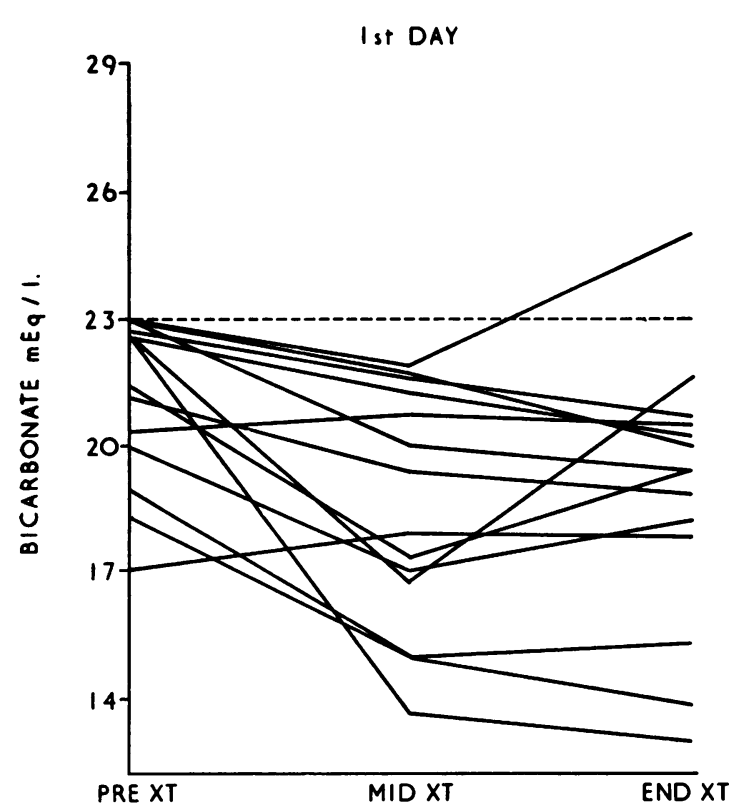

Fig. 1.-Plasma bicarbonate during exchange transfusion on 1st day of life in 14 babies (normal level $23 \mathrm{mEq} / 1$. indicated).

\section{Results}

Plasma Bicarbonate During Exchange Transfusion. 21 babies were studied, of between 37 and 40 weeks' gestation. They fell into two groups: (a) 14 babies transfused on the first day of life; many of these babies were anaemic, the $\mathrm{Hb}$ varying from 5.4 to $13 \cdot 8$, mean $10 \cdot 5 \mathrm{~g}$. $/ 100 \mathrm{ml}$.; (b) 7 babies transfused at 3-7 days old; the $\mathrm{Hb}$ level was higher in this group, ranging from $12 \cdot 5$ to $16 \cdot 5$, mean $14 \cdot 6 \mathrm{~g} . / 100 \mathrm{ml}$.

Fig. 1 shows the change in plasma bicarbonate in the 14 babies transfused on day 1 . The pre-exchange value ranged from 17 to $23 \mathrm{mEq} / \mathrm{l}$. During the first half of the 2-hour exchange transfusion the bicarbonate fell in 12 of the 14 cases. During the second half it continued to fall in some and rose in others, but with one exception the final value was less than $21.5 \mathrm{mEq} / \mathrm{l}$.

Fig. 2 shows comparable results for the 7 babies transfused when 3-7 days old. In 3 babies there was an initial fall in bicarbonate, but in 6 of the 7 the bicarbonate rose during the second half of the transfusion so that the final value was, with a single exception, higher than the pre-exchange value, and more than $23 \mathrm{mEq} / \mathrm{l}$.

Plasma Citrate During Exchange Transfusion. This was followed in 8 cases (Table 3). Despite the fact that the plasma citrate in the donor blood was

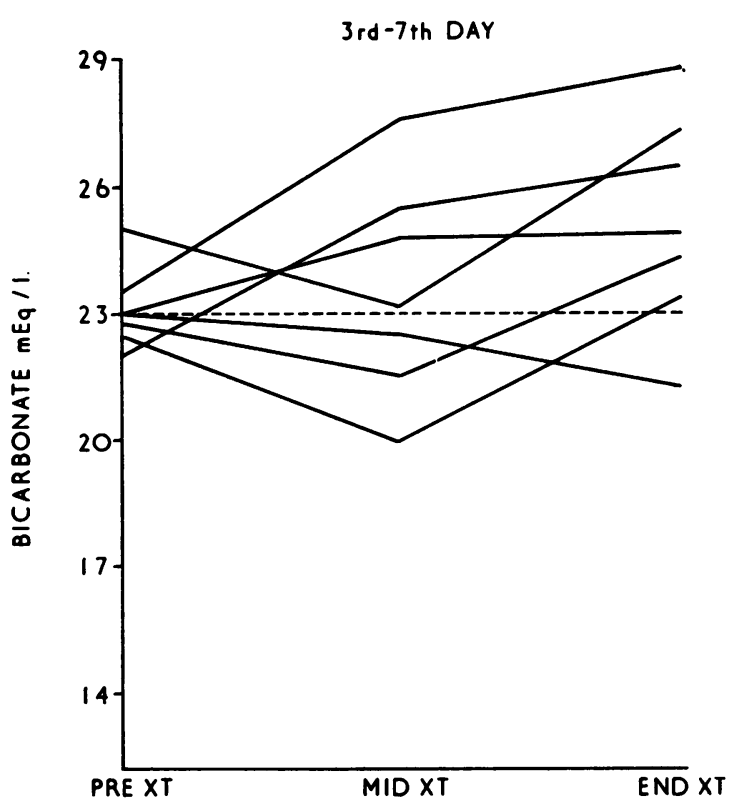

Fig. 2.-Plasma bicarbonate during exchange transfusion in 7 babies 3-7 days old.

about $620 \mathrm{mg} . / 100 \mathrm{ml}$, the highest level recorded during transfusion was $96 \mathrm{mg} . / 100 \mathrm{ml}$.

TABLE 3

PLASMA CITRATE LEVELS IN 8 BABIES RECEIVING EXCHANGE TRANSFUSION

\begin{tabular}{|c|c|c|c|}
\hline \multirow{2}{*}{ Case } & \multirow{2}{*}{ Age (days) } & \multicolumn{2}{|c|}{$\begin{array}{l}\text { Plasma Citrate Level: } \mathrm{mg} . / 100 \mathrm{ml} \text {. } \\
\text { (and } \mathrm{mM} / \mathrm{l} . \text { ) }\end{array}$} \\
\hline & & $\begin{array}{l}\text { Mid-exchange } \\
\text { (1 hour) }\end{array}$ & $\begin{array}{l}\text { End-exchange } \\
(2 \text { hours) }\end{array}$ \\
\hline $\begin{array}{l}1 \\
2 \\
3 \\
4 \\
5 \\
6 \\
7 \\
8\end{array}$ & $\begin{array}{l}1 \\
1 \\
1 \\
1 \\
3 \\
4 \\
4 \\
6\end{array}$ & $\begin{array}{l}44 \overline{(2 \cdot} \cdot 3) \\
36(1 \cdot 9) \\
96(5 \cdot 0) \\
13(0 \cdot 65) \\
58(3 \cdot 0) \\
48(2 \cdot 5) \\
\end{array}$ & $\begin{array}{ll}59 \cdot 5 & (3 \cdot 1) \\
96 & (5 \cdot 0) \\
51 & (2 \cdot 7) \\
39 & (2 \cdot 0) \\
27 & (1 \cdot 4) \\
77 & (4 \cdot 0) \\
78 & (4 \cdot 1) \\
57 & (3 \cdot 0)\end{array}$ \\
\hline
\end{tabular}

Plasma Chloride During Exchange Transfusion. Plasma chloride levels before and after transfusion were measured in 10 cases. Before transfusion the mean value was $104 \mathrm{mEq} / 1$. (range 97-107), after transfusion it was $95 \mathrm{mEq} / \mathrm{l}$. (range 81-101). In every case there was a fall in chloride, which averaged $9 \mathrm{mEq} / \mathrm{l}$.

It is useful to calculate the approximate amount of chloride removed from the body as a result of exchange transfusion. The mean concentration of 


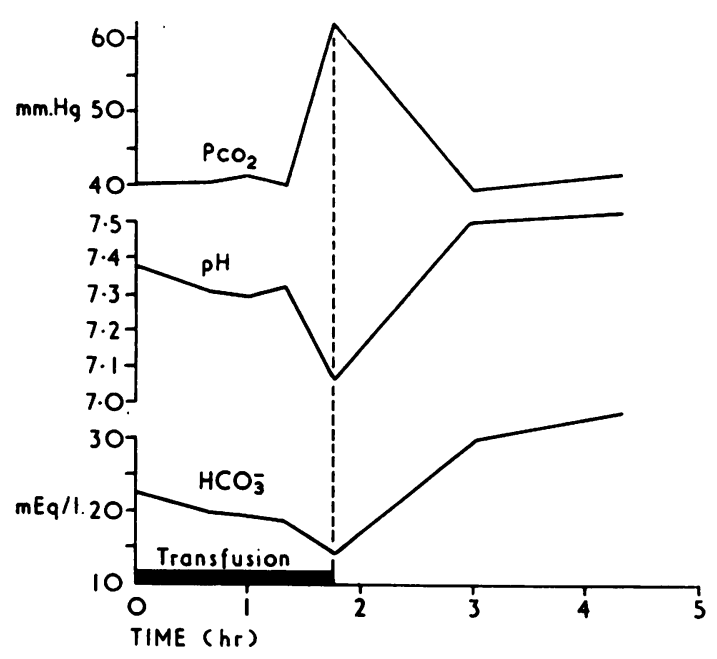

FIG. 3.- $-\mathrm{PCO}_{2}, p \mathrm{H}$, and bicarbonate of plasma in a premature baby who became ill towards the end of exchange transfusion. Note development of severe acidosis during transfusion, rapid correction after transfusion terminated, followed by development of alkalosis.

chloride in the effluent (10 cases) was $98 \mathrm{mEq} / \mathrm{l}$., and in the donor blood $63 \mathrm{mEq} / \mathrm{l}$. Since $180 \mathrm{ml} . / \mathrm{kg}$. of blood was exchanged, and assuming a haematocrit of $42 \%$ for both donor and recipient blood, the net loss of chloride was $(98-63) \times 180 / 1000 \times(100-42)$ $/ 100=3.7 \mathrm{mEq}$. per $\mathrm{kg}$. body weight.

Blood $p \mathrm{H}$ and $\mathrm{PCO}_{2}$ During Exchange Transfusion. Values for $p \mathrm{H}$ and $\mathrm{PCO}_{2}$ were obtained at the same time as those for bicarbonate in the 21 cases shown in Figs. 1 and 2, but have not been detailed here as they would have added little of importance. With few exceptions $\mathrm{PCO}_{2}$ remained near normal and within the range $37-46 \mathrm{~mm} . \mathrm{Hg}$, so that changes in $p \mathrm{H}$ ran parallel with changes in bicarbonate. The $p \mathrm{H}$ seldom fell below $7 \cdot 2$ and never below $7 \cdot 1$.

A different pattern was recorded, however, in a baby not included in the above series because it was premature, 36 weeks' gestation, $2 \cdot 4$ kg. (Fig. 3). Haemolytic disease was of moderate severity, the $\mathrm{Hb}$ being $10 \mathrm{~g} . / 100 \mathrm{ml}$.; exchange transfusion was carried out at 3 hours. During the first $1 \frac{1}{4}$ hours of the transfusion a mild metabolic acidosis developed, $\mathrm{HCO}_{3}^{-}$ falling from 22.5 to $18.5 \mathrm{mEq} / \mathrm{l}$, but the clinical state occasioned no anxiety until $1 \frac{3}{4}$ hours, when the baby's breathing became laboured and his colour pale. This abrupt clinical deterioration coincided with the development of a severe respiratory acidosis superimposed on a sharply increased metabolic acidosis, the $\mathrm{PCO}_{2}$ rising to $65 \mathrm{~mm} . \mathrm{Hg}$, and $\mathrm{HCO}_{3}^{-}$ falling to $13 \mathrm{mEq} / \mathrm{l}$. and $p \mathrm{H}$ to 7.03 . The trans-

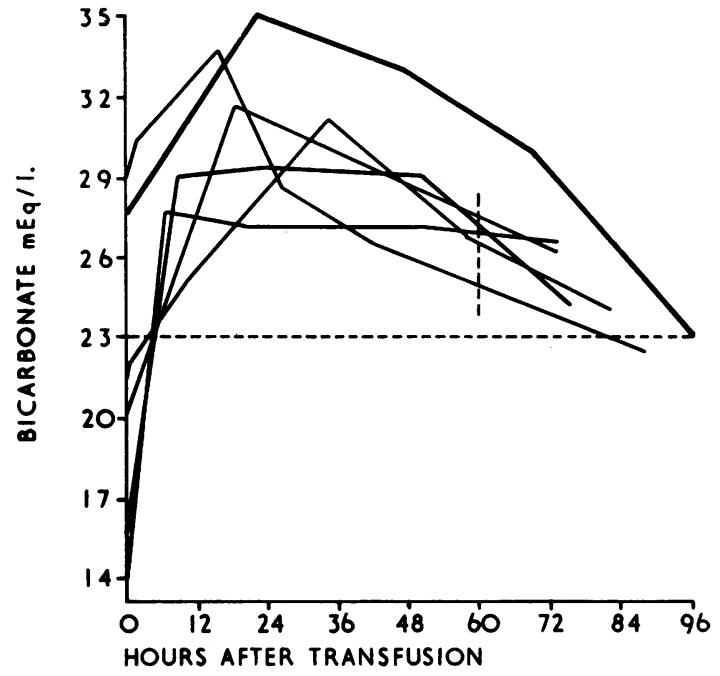

Fig. 4.-Plasma bicarbonate following exchange transfusion in 5 babies receiving one transfusion $(\longrightarrow)$, and in one baby $(-)$ receiving a second transfusion 36 hours after a transfusion on day 1 . At 60 hours bicarbonate is still raised.

fusion was stopped and the baby's condition thereafter improved rapidly, as did both the respiratory and metabolic acidosis (Fig. 3).

Plasma Sodium and Potassium During Exchange Transfusion. These remained within the normal range in 13 cases investigated. In no case did potassium reach $5 \mathrm{mEq} / \mathrm{l}$.

Plasma Bicarbonate Following Exchange Transfusion. This was determined in 5 cases after a single exchange transfusion, and in 1 case after a second exchange transfusion carried out 36 hours after an initial exchange at 4 hours old (Fig. 4).

The plasma bicarbonate rose rapidly after transfusion in all cases, so that the acidosis that was often present at the end of transfusion was replaced by an alkalosis within an hour or so (see also Fig. 3). During the first 24 hours after transfusion the bicarbonate in the 5 single-transfusion cases rose to between 27 and $33 \mathrm{mEq} / \mathrm{l}$., and to $35 \mathrm{mEq} / \mathrm{l}$. in the case receiving a second transfusion. The maximum $p \mathrm{H}$ in the same period was between 7.48 and 7.53 in 5 of these 6 cases, and was $7 \cdot 43$ in the remaining case.

Thereafter the bicarbonate level slowly fell, a period of more than 72 hours elapsing before a normal level of $23 \mathrm{mEq} / 1$. was reached.

It was pointed out to us by Dr. John Davies that the rate at which post-transfusion alkalosis was corrected might be limited by the amount of chloride 


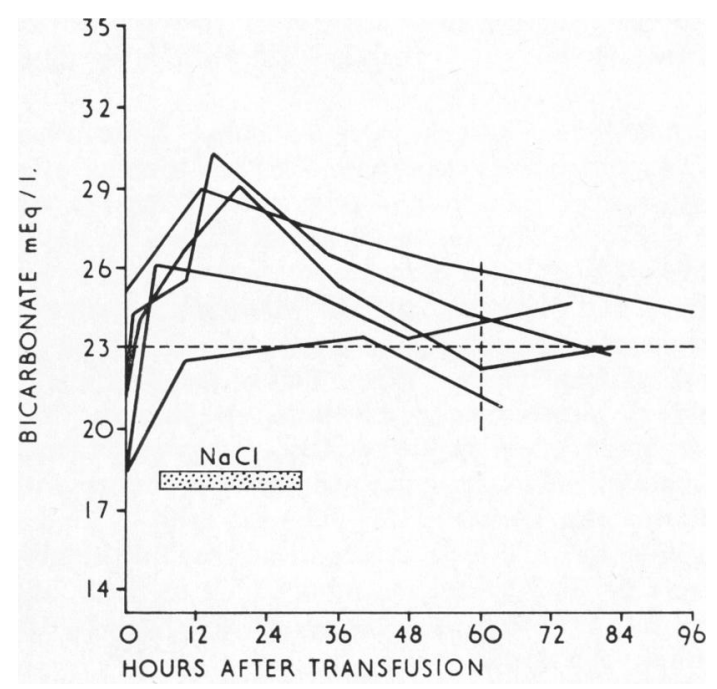

FIG. 5.-Plasma bicarbonate following exchange transfusion in 5 babies, to whom a supplement of $\mathrm{NaCl}(6-10 \mathrm{mEq} / \mathrm{kg}$.) was given.

At 60 hours the mean plasma bicarbonate is almost normal.

available to the baby, since the chloride content of milk, both human ( $12 \mathrm{mEq} / \mathrm{l}$.) and cows' $(29 \mathrm{mEq} / \mathrm{l}$.), is low. To test this idea we gave a supplement of $\mathrm{NaCl}, 6-10 \mathrm{mEq} / \mathrm{kg}$., to a series of 5 babies. The salt was given during the period 6-30 hours after transfusion, along with the ordinary feed. The 5 babies who received $\mathrm{NaCl}$ were comparable with the 5 who did not, 4 babies in each group having been transfused on the first day and 1 in each group on the fourth day of life.

Results are shown in Fig. 5. The babies receiving $\mathrm{NaCl}$ corrected the post-transfusion alkalosis somewhat more quickly. Comparing the two groups of babies at 60 hours after transfusion (Figs. 4, 5), in 4 out of the 5 babies receiving $\mathrm{NaCl}$ the bicarbonate level had by this time fallen below 24, while in 4 of the 5 controls the level was still above $27 \mathrm{mEq} / \mathrm{l}$. At 60 hours the mean bicarbonate level was $23 \cdot 3$ $\mathrm{mEq} / \mathrm{l}$. (SD 1.62) for the babies receiving $\mathrm{NaCl}$, and $26.6 \mathrm{mEq} / \mathrm{l}$. (SD 0.85 ) for the controls. The difference between the two means is highly significant (p $<0.001)$.

An alternative and more logical way of correcting a hypochloraemic alkalosis is to give $\mathrm{NH}_{4} \mathrm{Cl}$ rather than $\mathrm{NaCl}$, and the former was, therefore, given to a further 4 babies after transfusion. In 3 babies the dosage and timing of the $\mathrm{NH}_{4} \mathrm{Cl}$ administration was essentially similar to that of the group receiving $\mathrm{NaCl}, 5-8 \mathrm{mEq} / \mathrm{kg}$. being given along with the baby's milk feeds between 12 and 21 hours after transfusion

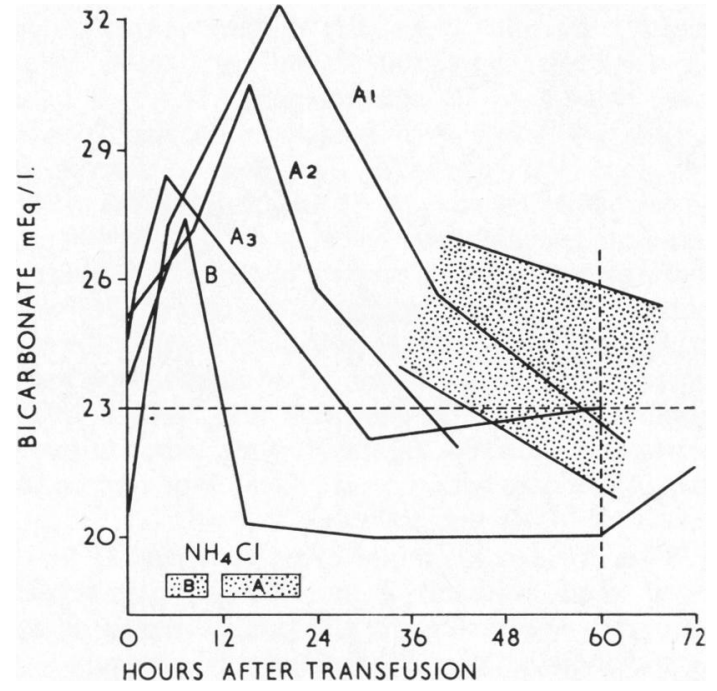

FIG. 6.-Plasma bicarbonate following exchange transfusion in 3 babies $\left(\mathrm{A}_{1}, \mathrm{~A}_{2}, \mathrm{~A}_{3}\right)$ given $\mathrm{NH}_{4} \mathrm{Cl} \mathrm{5-8} \mathrm{mEq} / \mathrm{kg}$., and in 1 baby (B) given $\mathrm{NH}_{4} \mathrm{Cl} 15 \mathrm{mEq} / \mathrm{kg}$. within the periods of time indicated. The shaded area includes the values for the 5 babies receiving $\mathrm{NaCl}$ as shown in Fig. 5.

(Fig. 6, Cases $A_{1}, A_{2}, A_{3}$ ). Comparing the rate at which the bicarbonate level of these babies fell to normal with the results for the $\mathrm{NaCl}$-treated group (shaded area in Fig. 6), it is seen that in one case $\left(A_{1}\right)$ the rate of fall was similar and in two cases $\left(\mathrm{A}_{2}, \mathrm{~A}_{3}\right)$ it was faster. A fourth case received a dose of $\mathrm{NH}_{4} \mathrm{Cl}$ which was both much larger $(15 \mathrm{mEq} / \mathrm{l}$.) and was given early, within 10 hours of the transfusion. This resulted (Case B, Fig. 6) in the post-transfusion alkalosis being rapidly overcorrected, the bicarbonate falling to $20 \mathrm{mEq} / \mathrm{l}$.

\section{Discussion}

Acid-base Changes During Exchange Transfusion. The acidosis occurring during exchange transfusion with citrated blood has been recorded by Povey (1964), who measured the $p \mathrm{H}$ of blood withdrawn from the umbilical vein. In 3 of his 6 cases the $p H$ fell below $7 \cdot 1$, which contrasts with the fact that in none of our 21 cases of more than 37 weeks' gestation did the $p \mathrm{H}$ fall below $7 \cdot 1$; indeed values below $7 \cdot 2$ were exceptional. His paper contains no description of the age, gestational age, or degree of anaemia of the cases, but one factor probably explaining the lower $p \mathrm{H}$ values occurring during transfusion in his series is that transfusions were usually completed in 50 to 90 minutes, as against the 120 minutes of our series.

Plasma citrate levels during exchange transfusion have been recorded by several authors, with divergent 
results. In our cases the highest citrate level recorded was $96 \mathrm{mg}$./100 ml., and comparable values were found by Wexler, Pincus, Natelson, and Lugovoy (1949) and by Anderson, Marks, Tomlinson, and Walker (1963). The latter authors in an earlier study (Anderson, Smith, and Walker, 1961) had found much higher levels up to $350 \mathrm{mg}$. $/ 100 \mathrm{ml}$., with the highest levels tending to occur in premature babies; the different results in the two studies were attributed to the fact that in the earlier study the rate of transfusion was faster (J. Anderson, personal communication). In Farquhar and Smith's (1958) series, levels of $100-200 \mathrm{mg}$. $/ 100 \mathrm{ml}$. were common, and in one case with a severe haemolytic disease the level rose to $346 \mathrm{mg} . / 100 \mathrm{ml}$.

Since for every 3 moles of citrate in ACD transfused (and retained) 2 moles when metabolized reappear as bicarbonate, the rate at which citrate is metabolized can conveniently be measured in terms of plasma bicarbonate. So measured, our results show that this rate is a function of a baby's age and/or its clinical status, since first-day babies, who in this series tended also to be moderately anaemic, metabolized citrate a good deal less rapidly than 3-7-day-old babies who were not anaemic (Figs. 1, 2). Thus at the end of transfusion, first-day babies showed a metabolic acidosis, while a metabolic alkalosis had usually already developed by the end of transfusion in the babies of 3-7 days old.

These facts can best be explained in terms of the functional efficiency of the liver, infused citrate being mainly metabolized in the liver. In our series, the younger group of babies was also the more severely affected by haemolytic disease (in terms of anaemia), so that we have been unable to separate two factors that may influence hepatic function - the age of the baby, and liver damage resulting from haemolytic disease. As regards the age factor, there is evidence that certain aspects of hepatic function (activity of glucuronyl transferase, bromsulphalein excretion) improve during the first few days after birth (see Smith, 1959), and it seems not unlikely that the capacity to metabolize citrate may behave similarly. That liver damage impairs the ability to metabolize citrate has been concluded both from observations on adult patients and from experiments on animals (Bunker, Stetson, Coe, Grillo, and Murphy, 1955; Sjöström, 1937).

In summary of this section: our own data, taken in conjunction with those of other workers quoted, are consistent with a conclusion that the severity of the acidosis developing during exchange transfusion is inversely related to the rate at which citrate is metabolized, and that this rate is probably slower in the premature than in the mature baby, in the anaemic or otherwise sick baby than in the well baby, and in the baby a few hours old than in the baby of a few days.

Acid-base Changes After Exchange Transfusion. Two components of the alkalosis developing after transfusion can be distinguished. One is the depletion of body chloride resulting from the use of donor blood with a chloride concentration only twothirds that of plasma: this was reflected in a lowering of plasma chloride by an average of $8 \mathrm{mEq} / \mathrm{l}$. by the end of transfusion. The other is the build-up of plasma bicarbonate as citrate is metabolized. The combined effect is to produce a hypochloraemic alkalosis, $p \mathrm{H}$ in our series rising to $7 \cdot 5$ or more, with plasma bicarbonate levels of up to $35 \mathrm{mEq} / 1$. In due course the alkalosis is corrected by the kidneys excreting $\mathrm{HCO}_{3}^{-}$and retaining $\mathrm{Cl}^{-}$in its place, and the rate at which this takes place is limited by the supply of chloride.

The amount of chloride removed as a result of exchange transfusion has been assessed at about 3.7 $\mathrm{mEq} / \mathrm{kg}$. body weight, representing about $7 \%$ of the total body chloride, which is $50 \mathrm{mEq} / \mathrm{kg}$. at birth (Forbes, Reid, Bondurant, and Etheridge, 1956). The depletion of chloride for a $3.5 \mathrm{~kg}$. baby must thus amount to $13 \mathrm{mEq}$, requiring for its replacement the ingestion by the baby of about 1 litre of human milk, or $\frac{1}{2}$ litre of cows' milk. These figures make it clear that the relatively small amount of chloride ingested by a baby in the first few days of life, particularly when taking breast milk, necessarily limits the rate at which the post-transfusion alkalosis can be corrected. Supplying additional chloride as $\mathrm{NaCl}$, or better as $\mathrm{NH}_{4} \mathrm{Cl}$, is shown to hasten correction of the alkalosis (Figs. 5, 6).

Practical Implications. The wisdom of employing a slow rate of transfusion is underlined, particularly in first-day babies and those with anaemia. Slow transfusion gives time for the initial acidosis to be offset by the alkalinizing effect of metabolized citrate. A slower rate of transfusion would probably have prevented the severe acidosis and clinical deterioration which developed in the case shown in Fig. 3.

There is some evidence to suggest that acidosis favours the passage of bilirubin from plasma, where it is largely bound to albumin, into cells, alkalosis favouring the reverse trend. Martin (1949), for instance, provides data showing that albumin binds $30 \%$ more bilirubin at $p \mathrm{H} 7 \cdot 6$ than at $7 \cdot 4$. Odell (1964) studied the partition of bilirubin in vitro between mitochondria and a solution of albumin, and concluded that 'any reduction in extracellular $p \mathrm{H}$ or addition of organic anions would favour 
intracellular diffusion of bilirubin displaced from albumin'. These facts imply that in any hyperbilirubinaemic situation it is particularly important to avoid acidosis developing during exchange transfusion. For the same reason, the posttransfusion alkalosis may be a positive advantage in hyperbilirubinaemia.

In the light of these facts, the pros and cons of concentrating citrated blood by removal of some plasma are worth considering.

The effects of concentrating donor blood are four:

(1) The baby will be left with a higher haematocrit and $\mathrm{Hb}$ level at the end of transfusion, which may obviate the need for a later top-up transfusion for anaemia.

(2) To the extent that the haematocrit at the end of transfusion is higher, the total circulating plasma protein is lower, and hence its binding capacity for bilirubin is lower.

(3) The amount of citrate administered will be less, hence the acidosis developing during transfusion will be lessened.

(4) The post-transfusion alkalosis will be diminished, which may perhaps be disadvantageous if there is hyperbilirubinaemia.

The first and third of these effects are advantageous and will usually be considered to outweigh the more marginal disadvantages of the second and fourth effects.

With the idea of offsetting the metabolic acidosis developing during exchange transfusion (Fig. 1). Boda, Tóth, Eck, and Murányi (1965) have advised giving an intravenous dose of sodium lactate to babies before transfusion, especially if an acidosis is already present. Povey (1964) suggested adding $\mathrm{NaHCO}_{3}$ or tris-buffer (THAM) to the donor blood. These approaches seem logical, particularly so if the baby is premature or affected by a severe degree of haemolytic disease. However, such procedures might well cause an exaggeration of the posttransfusion alkalosis, similar to that observed in the baby receiving a second exchange transfusion (Fig. 4). Although we have not discerned any clinical disorder resulting from the alkalosis $(p \mathrm{H}$ up to $7 \cdot 53)$ after transfusion with ACD blood, it would be unwise to assume that more severe degrees of alkalosis would be harmless.

\section{Summary}

Acid-base changes have been followed in 21 babies during exchange transfusion with citrated blood.
During exchange transfusion a metabolic acidosis developed initially. In the babies transfused on the first day of life, many of whom were also anaemic, the acidosis persisted throughout the course of a 2-hour transfusion. In older babies, 3-7 days of age, the initial acidosis was corrected by the end of transfusion.

Following exchange transfusion a hypochloraemic alkalosis developed and was not corrected until about the fourth day after transfusion.

Correction of post-transfusion alkalosis was accelerated by providing supplementary chloride, either as $\mathrm{NaCl}$ or $\mathrm{NH}_{4} \mathrm{Cl}$, because the amount of chloride available to the milk-fed baby is small relative to the depletion of chloride caused by exchange transfusion.

Certain practical implications of these findings are discussed.

Dr. John Davies's contribution, referred to in the text, is gratefully acknowledged. B.T.N. held a British Council Scholarship, and M.C. was supported by a Medical Research Council grant.

\section{REFERENCES}

Anderson, J., Marks, V., Tomlinson, R. W. S., and Walker, W. (1963). Changes in the blood concentration of glucose, $\alpha$-oxoglutarate, pyruvate and citrate during exchange transfusion in haemolytic disease of the newborn. Arch. Dis. Childh., 38, 481.

- Smith, B. M., and Walker, W. (1961). Certain biochemical changes during exchange transfusion. Vox Sang. (Basel), 6, 525.

Astrup, P., Jørgensen, K., Siggaard Andersen, O., and Engel, K. (1960). The acid-base metabolism: a new approach. Lancet, 1, 1035.

Boda, D., Tóth, G., Eck, E., and Murányi, L. (1965). pH changes in exchange transfusion. ibid., 1, 164.

Bunker, J. P., Stetson, J. B., Coe, R. C., Grillo, H. C., and Murphy, A. J. (1955). Citric acid intoxication. J. Amer. med. Ass., 157, 1361.

Farquhar, J. W., and Smith, H. (1958). Clinical and biochemical changes during exchange transfusion. Arch. Dis. Childh., 33, 142.

Forbes, G. B., Reid, A. F., Bondurant, J., and Etheridge, J. (1956). Changes in total body chloride during growth. Pediatrics, 17, 334.

Gandy, G., Grann, L., Cunningham, N., Adamsons, K., and James, L. S. (1964). The validity of $\mathrm{pH}$ and $\mathrm{PCO}_{2}$ measurements in capillary samples in sick and healthy newborn infants. ibid., 34, 192.

McArdle, B. (1955). A modified method for the microdetermination of citric acid. Biochem. J., 60, 647.

Martin, N. H. (1949). Preparation and properties of serum and plasma proteins. XXI. Interactions with bilirubin. J. Amer. chem. Soc., 71, 1230.

Odell, G. B. (1964). The influence of $\mathrm{pH}$ on the distribution of bilirubin between albumin and mitochondria. J. Pediat., 65, 1108.

Povey, M. J. C. (1964). pH changes during exchange transfusion. Lancet, 2, 339.

Sjöström, P. (1937). Der Citratgehalt im Blutserum als Diagnosticum bei Krankheiten der Leber und der Gallenwege: eine methodologische, tierexperimentelle und klinische studie. Acta chir. scand., Suppl. 49.

Smith, C. A. (1959). The Physiology of the Newborn Infant, 3rd ed. pp. 183-202. Blackwell, Oxford.

Wexler, I. B., Pincus, J. B., Natelson, S., and Lugovoy, J. K. (1949). The fate of citrate in erythroblastotic infants treated with exchange transfusion. J. clin. Invest., 28, 474. 